International Journal of Life Sciences
Available online at http://sciencescholar.us/journal/index.php/ijls
Vol. 3 No. 2, August 2019, pages: $1 \sim 7$
e-ISSN: 2550-6986, p-ISSN: 2550-6994
https://doi.org/10.29332/ijls.v3n2.286

\title{
Sugar Cane and Its Environmental Impact in Conton Junin, Province of Manabí
}

\author{
(1) corssark \\ Edison Fabián Sumba Sumba a , Jordán Alexander Moreira Cantos ${ }^{\text {b }}$, \\ Gabriel Fernando Calderón Intriago ${ }^{c}$
}

Article history: Received 27 December 2018, Accepted: 30 April 2019, Published: 17 May 2019

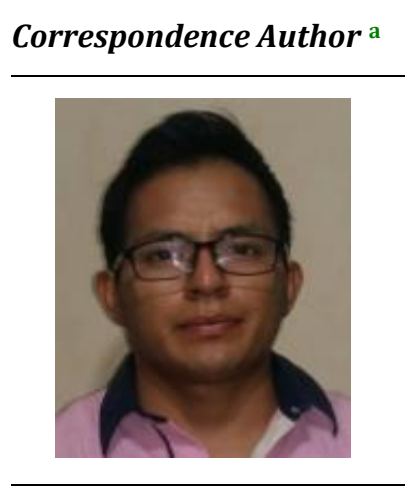

Keywords

bagasse;

integrated management;

pollution;

products;

waste;

\begin{abstract}
The Junín Canton is one of the largest producers of sugar cane in the province of Manabí, according to some experts, $87 \%$ of the population of that territory has linked to obtaining different products derived from this plant. The following research work makes some reflections related to the waste caused by the harvests and the environmental impact that has caused by not using them properly. The methodology used for the analysis has related to the field visits carried out in a research project, obtaining as a result that a large amount of bagasse has poured into the ground, or burned causing pollution affecting the ecosystem of the territory studied, waste, integrated management, waste, bagasse pollution.
\end{abstract}

e-ISSN: 2550-6986, p-ISSN: 2550-6994@ Copyright 2019. The Author. SS Journals Published by Universidad Técnica de Manabí. This is an open-access article under the CC BY-SA 4.0 license (https://creativecommons.org/licenses/by-sa/4.0/)

\section{Contents}

Abstract

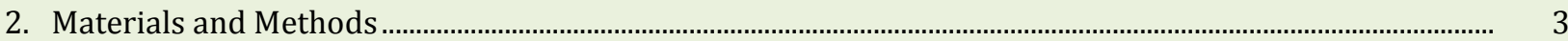

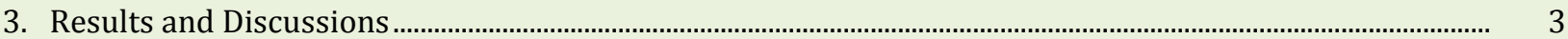

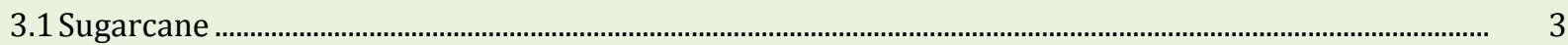

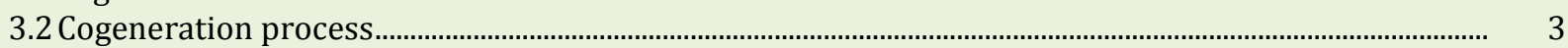

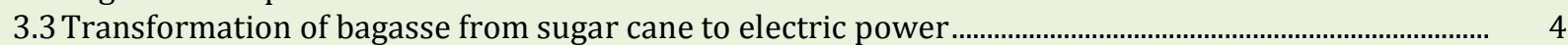

a Universidad Técnica de Manabí, Portoviejo, Ecuador

b Universidad Técnica de Manabí, Portoviejo, Ecuador

c Universidad Técnica de Manabí, Portoviejo, Ecuador 


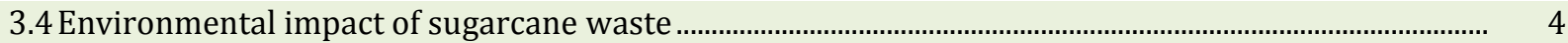

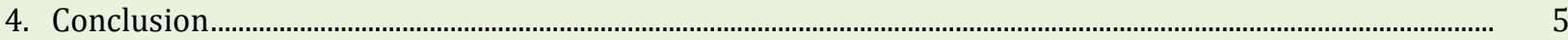

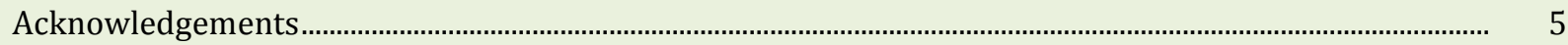

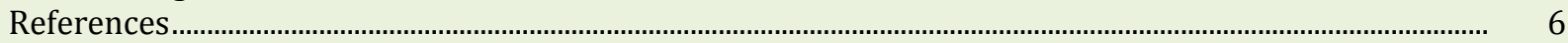

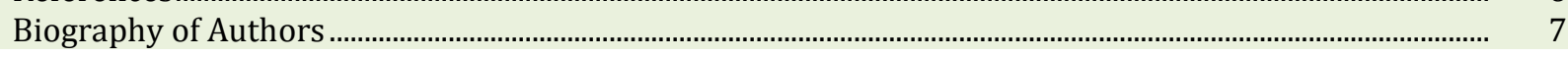

\section{Introduction}

Biomass is described as organic matter from plants or animals, including waste and waste, which has the potential to be harnessed as energy (Calvo, 2012). Within the biomass is all organic matter susceptible to energy use, in particular it can be said that the Spanish Association for Standardization and Certification (AENOR), uses the definition of the European Technical Specification CEN/TS 14588 to catalog biomass as all material of biological origin excluding those that have been found in geological formations undergoing a mineralization process (Velázquez, 2008).

This fact implies that biomass resources come from very diverse and heterogeneous sources. In addition, this heterogeneity and the technologies available or in development have allowed the energy products obtained to replace any conventional energy, be it a solid, liquid or gaseous fuel, both in thermal uses and in electrical uses. An example of biomass is found in the production of forest plantations, in these cases, the producer of biomass generated in the treatments and use of plant masses, are linked to the forestry sector and its activities in the forests.

The agricultural biomass is linked to the biomass production sector generated in the work of agricultural, woody and herbaceous crops, both in the work of pruning of trees and in the harvest and activities of collection of final products, directly linked to the agricultural sector and its activities, in the case of the forestry and agricultural industry, biomass is obtained by-products, by-products and waste generated in forestry and agricultural industrial activities, these have a close link with the industrial sectors; The biomass of part of the recovered wood, sawdust among others can also be considered in this section.

There are energy crops, where biomass is obtained from crops and/or uses (complete tree) of plant species specifically intended for production for energy use related to the forestry and agricultural sector. The products obtained can be used both for thermal purposes and to produce thermal or electrical energy so we can make a second division according to its application.

The biomass used for thermal purposes is used mainly in technological applications dedicated to the supply of heat for heating, production of ACS and/or industrial processes. It is clearly divided into applications for buildings, among other applications and for industrial processes. The most common types of biomass in thermal uses come from agricultural industries (olives bones and nutshells), forest industries (chips, chips, ...) and from forestry and woody crops (prunings, firewood, etc.).

Biomass that is used for the production of electricity through an exclusive process through cogeneration systems or combustion systems (Velázquez, 2008). Sugarcane is a tropical grass, a giant grass related to sorghum and corn, in whose stem it is formed and accumulates a juice rich in sucrose, it is found in the Junín area of the province of Manabí, it is used for the elaboration of different products such as panela, alfeñique, cane honey, sugar, etc., the product that is most elaborated is the cane brandy of the Junín canton known as Currincho. According to a report made by the provincial government, the productions do not use mechanized means, the mentality of the producers, the development of inadequate cultural practices and the problems that make marketing difficult (Herrera, 2015).

The production of sugarcane derivatives presents advantages to the sector because it has created jobs and small businesses that feed the province of its products being one of the opportunities offered by the productions of these small companies to the productive sector; In turn, a great problem is generated that is generated by the improper use of sugarcane waste, which is not properly assessed in such a way that waste is thrown from the cane after its production, which is known like the bagasse, the must among others. This bagasse when decompensated or burned and reduced to ashes creates great contamination to it, thus damaging the earth and its fertility.

It is a byproduct of bagasse can be used for the production of energy as the production of biogas that gives off in the erosion of its decomposition, you can also generate hydrogen-based fuels which can replace fossil 
fuels in the sector that are now scattered and that threaten the environment. The objective of this research work is to determine the amount of sugarcane bagasse residue that is obtained through its processing in the production of various values in the Junín canton.

\section{Materials and Methods}

A field investigation was carried out visiting the small factories or mills to verify all the sugarcane processing and to know what type of fuel they use and what they do with the residuals of the product, a survey was applied as an instrument for the development of the research, different producers were interviewed, the process of obtaining the product and the generation of waste was observed in some places. It was verified that the tropics have a chronogram of activities for the elaboration of their products.

\section{Results and Discussions}

\subsection{Sugarcane}

Its scientific name (Saccharum officinarum L) is a tropical grass, a giant grass related to sorghum and corn, in whose stem it forms and accumulates a juice rich in sucrose, a compound that when extracted and crystallized in sugar, forms sugar, Sucrose is synthesized by the cane thanks to the energy taken from the sun during the process of photosynthesis (Perafan, 2009).

In many countries such as Brazil (Cabrera, 2010), and Cuba (Abreu, 2016), it is used for cogeneration, which is a process by which electrical, mechanical and thermal energy is produced simultaneously. The sugar sector has been indicated by national and international studies like the one with the greatest potential for cogeneration due to its availability of biomass, especially bagasse. This by-product, derived from cane harvesting and milling processes, is the primary source of energy for cogeneration.

\subsection{Cogeneration process}

This process corresponds to the generation of energy as part of the productive process, either sugar or ethanol. The mills since its inception have used cane bagasse (renewable fuel) as fuel to power their boilers and use steam as energy for the operation of their processes. The cogeneration then uses the energy in the form of heat produced by the bagasse to generate steam and then through the use of turbogenerators, the electrical energy. The exhaust steam of the turbogenerator then goes to the production process while the electricity is mostly used for its own consumption and a portion is sold to the national grid. Part of the bagasse is also used in the paper industry as a source of fiber, which prevents the felling of trees (Bioenergía, 2017).

One of the additional advantages of cogeneration is the provision of a reserve of electrical energy in the production centers. In fact, if a supply cut occurs from the local distributor, due to network failures or shortages, the production process has a minimum margin of electrical energy with which critical work can be done without stopping the production line. Another important advantage is the reduction of air pollution since this technology is less polluting than other fossil fuels used in the generation of electricity (Loyola, 2008).

The production of energy obtained from renewable sources is based on the spontaneous or induced degradation of any type of organic matter that has had its immediate origin, as a consequence of a biological process and all vegetal matter originated by the process of photosynthesis, as well as of the metabolic processes of heterotrophic organisms, and that does not contain or have been in contact with trace elements that confer some degree of danger (Ackermann, 2005).

The use of sugarcane biomass in Ecuador, mainly in the Manabí area where there is a high potential for biomass and especially sugarcane could lead to a positive change in energy saving and support for the change in the energy matrix to the region and that in the current moments these residues are not used efficiently as well as the use of the must for its use of energy production with biogas or fuels based on hydrogen cells from ethanol.

Sumba, E. F. S., Cantos, J. A. M., \& Intriago, G. F. C. (2019). Sugar cane and its environmental impact in conton junin, province of manabí. International Journal of Life Sciences, 3(2), 1-7. https://doi.org/10.29332/ijls.v3n2.286 
By adequately using sugarcane biomass (bagasse and sugarcane agricultural residues), and with the introduction of new technologies, the efficiency in electric generation in the sugar industry is increased and environmental pollution is greatly reduced (Reyes et al., 2018). Figure 1 shows the residuals of bagasse in small industries.

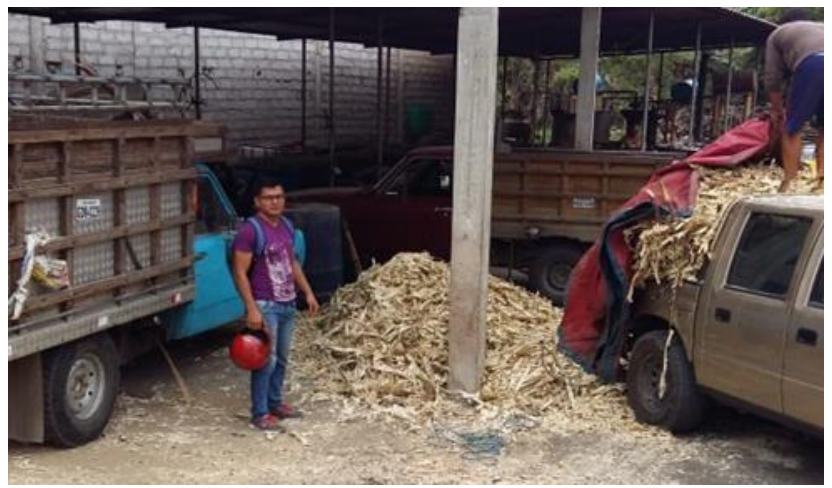

Figure 1. Residual of bagasse

\subsection{Transformation of bagasse from sugar cane to electric power}

Thousands of tons of bagasse leave daily as waste by squeezing every last drop of cane, a product that has long played an important role in the generation of electric power (Guzmán, 2018). By using the residues of the production of sugarcane by-products to generate energy, the prices of electric power would decrease and some stability would remain since they do not depend totally on the international electricity market, which positively influences the consumer's bill final.

Each mill produces different volumes of waste since each one processes different amounts in tons of cane and therefore of bagasse. At present, the production of energy through bagasse of sugarcane shows a growth of about 7.5\%, this being its presence within the energy matrix, according to figures from the transaction unit. (Guzmán, 2018).

The cane bagasse is taken by means of conveyor belts to the thermoelectric plant and deposited in the furnace of the boiler, to be burned. The bagasse by its very nature burns practically instantly upon being deposited in a boiler. Inside the boiler there is an internal air injection system to create the turbulence, so that once it enters the kiln it is scattered throughout the area of this and a swirl is created so that it burns in the air instantly, then the bagasse is burnt, the ash is collected and discarded, and the combustion gases deliver the energy to the different stages of the boiler process, between walls of water, over heaters, economizer and air economizer to generate the steam to the conditions adequate.

The gases pass through the electrostatic processor, so as not to emit off-normal gases into the environment, later the steam generated is transported by means of pipes to the turbine that converts it into mechanical energy, to move the generator which in turn converts the steam in electrical energy (Guzmán, 2018).

\subsection{Environmental impact of sugarcane waste}

The sugar industry discards between $20 \%$ and $25 \%$ on a wet basis of cane harvest residues, currently it is usually burned and it is not used at the best of things it is fed to livestock, but the worst is cases are burned, causing negative impacts to the soil, air and, in many cases, water. This waste could be used to generate energy in small bioenergies that can sustain their production, achieving energy sustainability and indirectly solving an environmental problem (Sánchez, 2013).

Among the main environmental impacts of sugarcane cultivation are the effects on soil, rivers, and groundwater due to the use of pesticides, soil compaction, due to the intensive use of agricultural machinery, erosion, and polluting emissions. the practice of burning sugarcane before harvest, and impoverishment of 
biological diversity (plant and animal) due to the elimination of all living beings by the expansion of this monoculture (Zoratto, 2006).

In the area of Junín, in Manabí, which is a potential producer of sugarcane for the production of various products, among the most famous is the cane brandy called Currincho, in the production of this product a large amount of waste is generated. bagasse, which is not given the due importance at the time of discarding its waste, generating negative impacts to the soil, because the bagasse is burned and the ashes affect the quality of the land, being able to be used to produce energy through the process of cogeneration.

\section{Conclusion}

In the Junín Canton, a large amount of sugarcane is harvested and there are small and medium industries that process the byproducts that supply the province; but the residuals they produce in their processes, such as bagasse and the must of production, are dumped into the ground, or burned, causing pollution levels in the ecosystem.

\section{Acknowledgments}

The authors thank the producers of Conton Junin for having done this research that would help in the future to culturize them so that this process of contamination decreases and energy can be generated achieving the sustainability of the productions.

Sumba, E. F. S., Cantos, J. A. M., \& Intriago, G. F. C. (2019). Sugar cane and its environmental impact in conton junin, province of manabí. International Journal of Life Sciences, 3(2), 1-7. 


\section{References}

Abreu Elizundia, H., González Cortés, M., Rico Ramírez, O., Morales Zamora, M., \& Espinosa Pedraja, R. (2016). Evaluation of energy cogeneration schemes from sugarcane bagasse. Sugar Center ,

Ackermann, T. (Ed.). (2005). Wind power in power systems(Vol. 140). Chichester, UK: John Wiley.

Bioenergía. (2017). Bioenergía. Recuperado el 5 de Noviembre de 2018, de Sector Agroindustrial de la caña: https://www.asocana.org/documentos/562017-bc7b477d00ff00,000a000,878787,c3c3c3,0f0f0f,b4b4b4,ff00ff,2d2d2d.pdf

Cabrera, JA, \& Zuaznábar, R. (2010). Sugarcane response to nitrogen fertilization in a long-term experiment with 24 accumulated harvests. Tropical crops , 31 (1), 00-00.

Calvo, M. (2012). ¿ Qué son las Energías Renovables. https://twenergy.com/a/que-es-la-biomasa-738

Herrera, M. E. B. (2015). Creating competitive advantage by institutionalizing corporate social innovation. Journal of Business Research, 68(7), 1468-1474. https://doi.org/10.1016/j.jbusres.2015.01.036

Lee, N. J., Kothari, P., Phan, K., Shin, J. I., Cutler, H. S., Lakomkin, N., ... \& Cho, S. K. (2018). Incidence and risk factors for 30-day unplanned readmissions after elective posterior lumbar fusion. Spine, 43(1), 41-48. https://www.elsalvador.com/noticias/negocios/439746/como-se-transforma-el-bagazo-de-cana-deazucar-a-energia-electrica/

Loyola, R. D., De Oliveira, G., Diniz-Filho, J. A. F., \& Lewinsohn, T. M. (2008). Conservation of Neotropical carnivores under different prioritization scenarios: mapping species traits to minimize conservation conflicts. Diversity and Distributions, 14(6), 949-960. https://doi.org/10.1111/j.1472-4642.2008.00508.x

Montiel, JLR (2003). The cane biomass as an alternative to increase energy efficiency and reduce environmental pollution. Centro Azúcar , 30 (2), 14-21.

Perafan, F. (2009). Sugar cane. Retrieved from Sugar cane. http://www.perafan.com/azucar/ea02cana.html

Sanchez, C. (2013). Energynew. Obtenido de Los residuos de la caña de azúcar se podrían aprovechar para biomasa con la tecnología de gasificación. https://www.energynews.es/los-residuos-de-la-cana-de-azucarse-podrian-aprovechar-para-biomasa-con-la-tecnologia-de-gasificacion/

Velásquez, JR, \& Ceballos, YF (2008). Study of an innovation process using systems dynamics. Notebooks of administration, 21 (35).

Zoratto, A. (2006). Estudo dos Impactos Ambientais da Industria Canavieira. II Fórum de Meio Ambiente da Alta Paulista. 


\section{Biography of Authors}

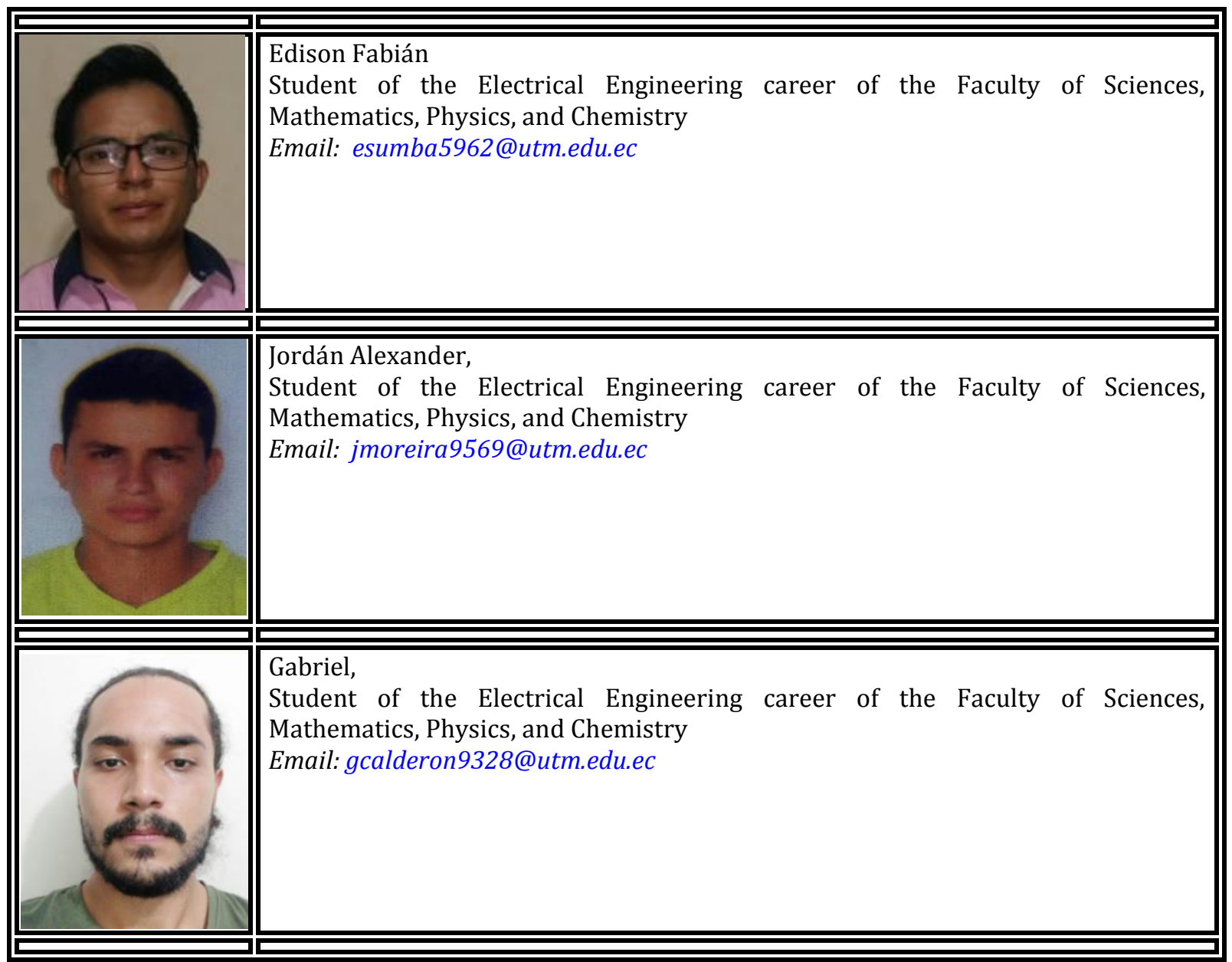

Sumba, E. F. S., Cantos, J. A. M., \& Intriago, G. F. C. (2019). Sugar cane and its environmental impact in conton junin, province of manabí. International Journal of Life Sciences, 3(2), 1-7. https://doi.org/10.29332/ijls.v3n2.286 